\title{
SYNTHESIS OF AN ENANTIO-ENRICHED IRIDOLACTONE CORE IN BRASOSIDE.
}

MAKAMA, B. Y.

Department of Petroleum Chemistry

American University of Nigeria, Lamido Zubairu Way

P.M.B. 2250, Yola, Adamawa State, Nigeria.

bello.makama@aun.edu.ng

\section{Abstract}

A three step enantio-enriched protocol to the iridolactone core of brasoside is reported. Stereo-control reduction of [(1S,2R,3S)-3-methyl-2(nitromethyl)-5oxocyclopentyl]acetic acid 3 afforded (3aR,4S,5R,6aS)-5-methyl-4(nitromethyl)-hexahydrocyclopenta[b]furan-2-one 4. A further formylation strategy on the AB-ring system $\mathbf{4}$ afforded the enol ester $\mathbf{5}$, followed by Ne reaction of the nitoo functionality and acid quenching to the desired tricyclic lactone 11. Chiral $\square$-keto-acid 3 was used, since this precursor contains three functional groups: ketone, carboxylic acid, nitromethyl; it is also available in bulk as a pure enantiomer at low price.

Keywords: three step enantio-enriched, iridolactone, brasoside, formylation, enol ester, Nef reaction, tricyclic lactone)

\section{INTRODUCTION}

Brasoside was first isolated from Verbena littoralis H. B. K (Verbenaceae), a plant which has been widely used as a traditional folk medicine for the treatment of diarrheoa, typhoid and tonsillitis in South America. More recently, the crude extract of $V$. littoralis was shown to potentiate NGF-induced neurite outgrowth from PC12D cells (Umana \& Castro, 1990). Ishibashi et al., (2001) were the first to report the successful isolation and structural elucidation of brasoside 1 as one of four iridoid or iridoid glycoside compounds isolated from Verbena littoralis. In the nine years since the isolation of brasoside, very few approaches to the synthesis of the natural product have been reported (Ford et al., 2004; Mangion \& Macmillan, 2005).

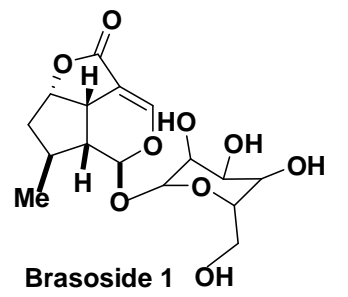<smiles>CC(=O)OC1OC=C2C(=O)OC3CC(C)CC1C23O</smiles>
Iridolactone Core 2

\section{FIG. 1. BRASOSIDE}

As part of a programme aimed at the rapid and efficient synthesis of complex iridoids natural products, herein it is reported, an efficient synthetic approach to the tricyclic core 4 in Brasoside 1 via stereoselective reduction of $[(1 S, 2 R, 3 S)-3-$ methyl-2(nitromethyl)-5oxocyclopentyl]acetic acid $\mathbf{3}$ (Scheme 1).

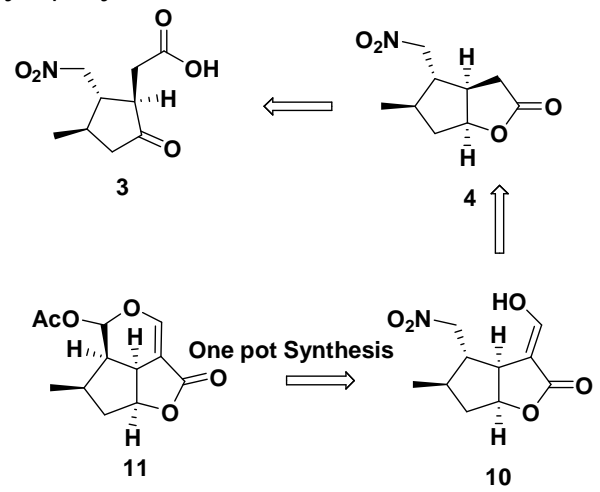

\section{MATERIALS AND METHODS}

Reagents were obtained from Aldrich and Lancaster chemical suppliers. Dichloromethane was refluxed over and distilled from $\mathrm{CaH}_{2}$ prior to use. Diethyl ether was obtained dry from Aldrich. THF was dried by distillation from the sodium benzophenone ketyl radical under nitrogen. Light petroleum is the fraction of petroleum ether that boils in the range $30-40{ }^{\circ} \mathrm{C}$, was fractionally distilled through a $36 \mathrm{~cm}$ Vigreux column before use (Amarego \& Perrin, 1998).

Organic solutions were concentrated under reduced pressure on a Büchi rotary evaporator using a water bath. Thin-layer chromatography (TLC) was performed on Merck aluminium-backed plates coated with $0.2 \mathrm{~mm}$ silica gel 60-F plates. Visualization of the developed chromatogram was performed by UV fluorescence quenching at $254 \mathrm{~nm}$, or by staining with a $\mathrm{KMnO}_{4}$ solution. ${ }^{1} \mathrm{H}$ and ${ }^{13} \mathrm{C}$ NMR spectra were recorded on a Bruker DPX250 (250 MHz for protons) and a Brüker AMX400 (400 MHz for protons). Data for ${ }^{1} \mathrm{H}$ NMR were reported as follows: chemical shift ( $\delta$-ppm), multiplicity $(s=$ singlet, $d=$ doublet, $\mathrm{t}=$ triplet, $\mathrm{q}=$ quartet, $\mathrm{m}=$ multiplet), integration, coupling constant in $(\mathrm{Hz})$. Data for ${ }^{13} \mathrm{C}$ NMR spectra were reported in terms of chemical shift (ppm) down field from TMS. IR spectra were recorded on a Perkin Elmer Paragon 1000 and a Perkin Elmer 881 spectrometer as a thin film between sodium chloride plates. Absorptions were measured $\left(\mathrm{cm}^{-1}\right)$. Mass spectrometric data were recorded on VG Autospec, under conditions of chemical ionisation (C.I) using ammonia as the ionising source. Peaks were quoted in the form (m/z) (relative intensity). Melting points were determined using a Reichert Kofler heated-stage microscope and were uncorrected.

\section{(3aR,4S,5R,6aS)-5-methyl-4-(nitromethyl)-} hexahydrocyclopenta[b]furan-2-one 4

Method A : To a stirred solution of $[(1 S, 2 R, 3 S)-3$-methyl2(nitromethyl)-5-oxocyclopentyllacetic acid 3 ( $5 \mathrm{~g}, 23.2 \mathrm{mmol}, 1.00$ equiv) in THF $(80 \mathrm{~mL})$ at $-78{ }^{\circ} \mathrm{C}$ was added K-Selectride ${ }^{\circledR} 1 \mathrm{M}$ solution in THF ( $6.0 \mathrm{~g}, 30.2 \mathrm{mmol}, 1.30$ equiv). The reaction mixture was stirred under nitrogen for 1 hour, followed by the addition of $2 \mathrm{M}$ $\mathrm{NaOH}(7 \mathrm{~mL})$ and $\mathrm{H}_{2} \mathrm{O}_{2}(15 \mathrm{~mL})$ successively via syringe. The reaction was warmed to room temperature, extracted with ether $(4 \mathrm{x}$ $15 \mathrm{~mL}$ ). The combined organic layers were washed twice with saturated $\mathrm{NH}_{4} \mathrm{Cl}(2 \times 10 \mathrm{~mL})$, dried over $\mathrm{MgSO}_{4}$ and concentrated in

vacuo to give a green oil, which was dissolved in ice water $(20 \mathrm{~mL})$ and further acidified to $\mathrm{pH} 2$ with $2 \mathrm{~N} \mathrm{HCl}$ to give a pale green oil. Flash chromatography on silica eluting with hexane : ether (1:1)

\section{2-(1R,2S,3R,5R)-5-hydroxy-3-methyl-2-} (nitromethyl)cyclopentyl)acetic acid 6

Method B: To a stirred solution of [(1S,2R,3S)-3-methyl2(nitromethyl)-5-oxocyclopentyl]acetic acid $3(2.00 \mathrm{~g}, 9.95 \mathrm{mmol}$ 1.00 equiv) in THF $(30 \mathrm{~mL})$ at $-78{ }^{\circ} \mathrm{C}$ was added L-Selectride ${ }^{\circledR}(2.29$ $\mathrm{g}, 12.08 \mathrm{mmol}, 1.30$ equiv). The reaction mixture was stirred under nitrogen for 1 hour, followed by the addition of $2 \mathrm{M} \mathrm{NaOH}(6 \mathrm{~mL})$ and $\mathrm{H}_{2} \mathrm{O}_{2}$ (10 mL) via syringe. The reaction was warmed up to room temperature and the organic layer was extracted with ether $(4 \times 15$ $\mathrm{mL}$ ). The combined organic layers were washed twice with saturated $\mathrm{NH}_{4} \mathrm{Cl}(2 \times 7 \mathrm{~mL})$, dried over $\mathrm{MgSO}_{4}$ and concentrated in vacuo to give a dark green oil. Flash chromatography on silica eluting with hexane : ether (1:1) 
(3a, $R, 4 S, 5 R, 6 a S)$-4-(aminomethyl)-5-methylhexahydrocyclopenta[b]furan-2-one 5

Method C: To a stirred solution of $[(1 S, 2 R, 3 S)-3-m e t h y l-$ 2(nitromethyl)-5-oxocyclopentyl]acetic acid $3(2.00 \mathrm{~g}, 9.95 \mathrm{mmol}$ 1.00 equiv) in ethanol $(30 \mathrm{~mL})$ in an Erlenmeyer flask was added $\mathrm{NaBH}_{4}$ at room temperature (489 mg, $12.94 \mathrm{mmol}, 1.30$ equiv) in small portions over a period of 15 minutes. The reaction resultant mixture was stirred for further 30 minutes and then poured into ice water $(10 \mathrm{~mL})$, followed by the addition of dilute hydrochloric acid $(5 \%)$ until the $\mathrm{pH} 2$ was reached, by which time, TLC analysis showed a new product has been formed. The aqueous layer was extracted with ether $(4 \times 10 \mathrm{~mL})$, the extract dried over $\mathrm{MgSO}_{4}$ and concentrated in vacuo. Column chromatography on silica, eluting with hexane : ether $(5: 1)$

(3aS,4S,5R,6aS,Z)-3-(hydroxmethylene)-5-methyl-4(nitromethyl)-hexahydrocyclopenta[b]furan-2-one 10

To a stirred suspension of sodium hydride $55-60 \%$ dispersion in mineral oil washed in hexane (152 mg, $4.0 \mathrm{mmol}, 4.00$ equiv) in dry ether $(10 \mathrm{~mL})$ under argon, at $0{ }^{\circ} \mathrm{C}$, was added (3aR,4S,5R,6aS)-5methyl-4-(nitromethyl)-hexahydrocyclopenta[b]furan-2-one 4 (200 $\mathrm{mg}, 1.0 \mathrm{mmol}, 1.00$ equiv) via syringe. The reaction was allowed to stir for further 5 minutes, followed by the addition of ethyl formate (296 mg, $4.0 \mathrm{mmol}, 4.00$ equiv). The reaction mixture was stirred at room temperature for another 20 hours by which time the starting materials had been fully consumed. The reaction was quenched with $5 \% \mathrm{HCl}(2 \mathrm{~mL})$ and extracted with ethyl acetate $(4 \times 15 \mathrm{~mL})$. The combined organic layers were washed with saturated $\mathrm{NaHCO}_{3}(4 \mathrm{x}$ $10 \mathrm{~mL}$ ), dried over $\mathrm{MgSO}_{4}$ and concentrated in vacuo to give a yellowish oil. Column chromatography eluting with hexane : ethyl acetate (3:1)

\section{Iridolactone 11}

To a stirred solution of (3aS,4S,5R,6aS,Z)-3-(hydroxmethylene)-5methyl-4-(nitromethyl)-hexahydrocyclopenta[b]furan-2-one 10 (200 $\mathrm{mg}, 0.88 \mathrm{mmol}, 1$ equiv) in $\mathrm{H}_{2} \mathrm{O}(3 \mathrm{~mL})$ was added a solution of $\mathrm{NaOH}$ ( $352 \mathrm{mg}, 88.0 \mathrm{mmol}, 10$ equiv) in $\mathrm{H}_{2} \mathrm{O}(5 \mathrm{~mL}$ ) and then added dropwise an ice cold solution of concentrated $\mathrm{H}_{2} \mathrm{SO}_{4}(2 \mathrm{~mL})$ in $(7$ $\mathrm{mL}$ ) of $\mathrm{H}_{2} \mathrm{O}$. Stirring was continued for 1 hour at $0^{\circ} \mathrm{C}$ and acetic anhydride1 $\mathrm{mL}$ was added, and the solution was allow to stir for 12 hours, by which time TLC analysis showed a new product been formed, $\mathrm{H}_{2} \mathrm{O}(5 \mathrm{~mL})$ was added to the mixture and the organic layer was extracted with ethyl acetate $(4 \times 15 \mathrm{~mL})$. The combined organic layers were dried over $\mathrm{MgSO}_{4}$ and concentrated in vacuo. The residue was purified by column chromatography on silica gel using hexane : ethyl acetate (1:1)

\section{RESULTS}

(3aR,4S,5R,6aS)-5-methyl-4-(nitromethyl)hexahydrocyclopenta[b]furan-2-one 4

Method A : The title compound $\mathbf{4}$ was isolated as a colourless oil $(3.9 \mathrm{~g}, 85 \%) ; \quad V_{\max }$ (thin film) 2968, 2931, 1769, 1550, 1381 $1172 ; \delta_{\mathrm{H}}\left(400 \mathrm{MHz}, \mathrm{CDCl}_{3}\right) 4.92(1 \mathrm{H}, \mathrm{q}, \mathrm{J} 5.2 \mathrm{~Hz}, \mathrm{~J} 2.2 \mathrm{~Hz}, \mathrm{CHO}$ ), $4.6\left(1 \mathrm{H}, \mathrm{dd}, \mathrm{J} 7.5 \mathrm{~Hz}, \mathrm{~J} 4.7 \mathrm{~Hz}, \mathrm{CH}_{2} \mathrm{NO}_{2}\right), 4.37(1 \mathrm{H}, \mathrm{dd}, \mathrm{J} 8.4$ $\left.\mathrm{Hz}, J 3.8 \mathrm{~Hz}, \mathrm{CH}_{2} \mathrm{NO}_{2}\right), 2.78(1 \mathrm{H}, \mathrm{dd}, J 9.8 \mathrm{~Hz}, J 8.4 \mathrm{~Hz}, \mathrm{~J} 1.6$ $\left.\mathrm{Hz}, \mathrm{CH}_{2} \mathrm{C}=0\right), 2.73(1 \mathrm{H}$, ddd, J $5.6 \mathrm{~Hz}, \mathrm{~J} 1.9 \mathrm{~Hz}, \mathrm{CHCHO}), 2.54-$ $2.47\left(1 \mathrm{H}, \mathrm{m}, \mathrm{CH}_{2} \mathrm{CHO}\right), 2.44(1 \mathrm{H} \mathrm{dd}, \mathrm{J} 15.9 \mathrm{~Hz}, J 1.9 \mathrm{~Hz}$, $\left.\mathrm{CH}_{2} \mathrm{C}=0\right), 2.06-2.03\left(1 \mathrm{H}, \mathrm{m}, \mathrm{CHCH}_{2} \mathrm{NO}_{2}\right), 1.82-1.78(1 \mathrm{H}, \mathrm{m}$, $\left.\mathrm{CHCH}_{3}\right), 1.62-1.54\left(1 \mathrm{H}, \mathrm{m}, \mathrm{CH}_{2} \mathrm{CHO}\right), 1.11(3 \mathrm{H}, \mathrm{d}, J 6.5 \mathrm{~Hz}$, $\left.\mathrm{CH}_{3}\right) ; \delta_{c}\left(100 \mathrm{MHz}, \mathrm{CDCl}_{3}\right)$ 176.2, 83.1, 77.4, 50.5, 43.5, 40.6, 37.4, 34.0, 17.4; m/z (C.I) $200\left(\mathrm{MH}^{+}, 100 \%\right), 182(54 \%), 153$ (58\%), 131 (60\%), $108(40 \%), 82$, (21\%) $\mathrm{C}_{9} \mathrm{H}_{14} \mathrm{NO}_{4}$, requires 200.0924, found 200.0916

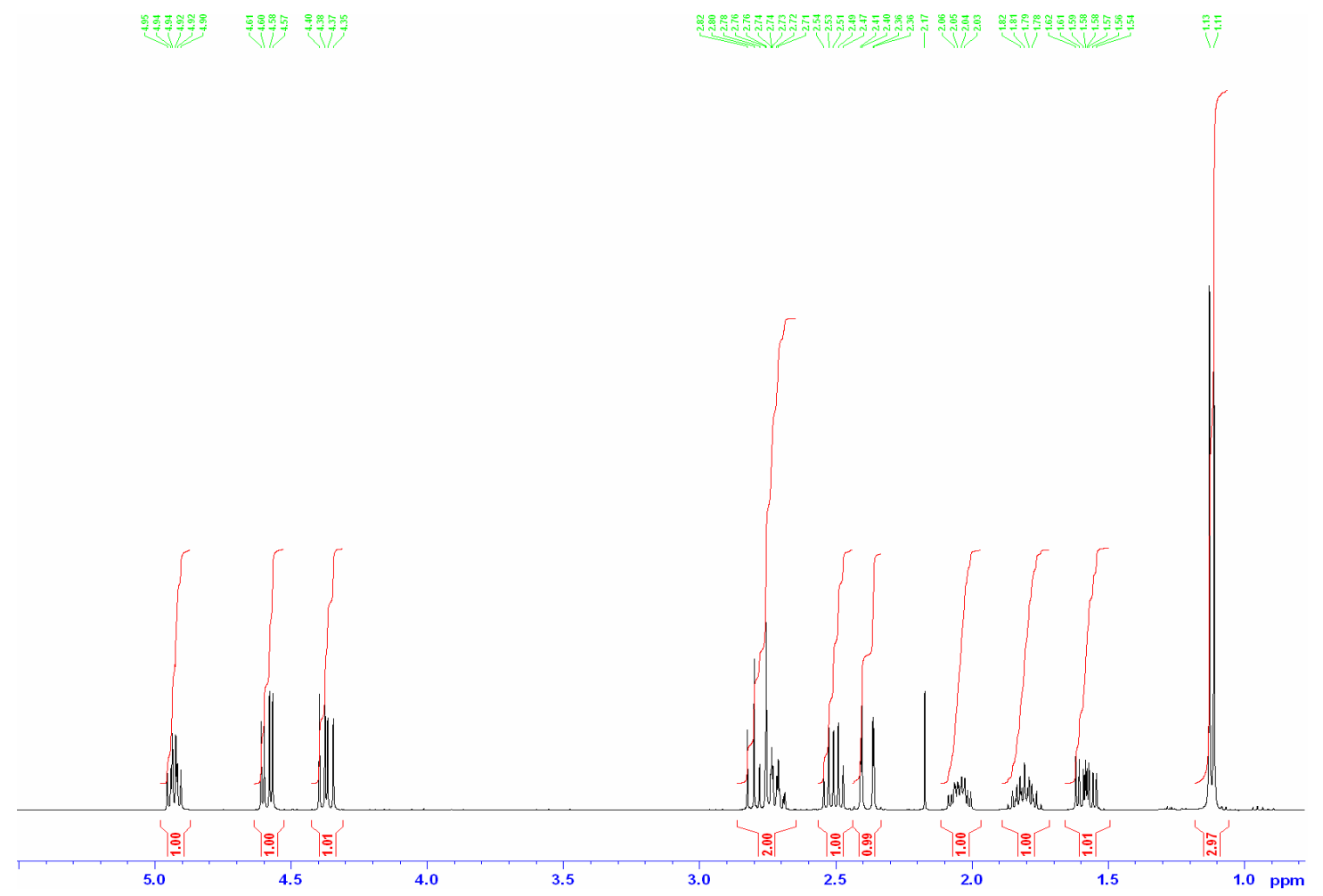

FIG. 2. H NMR OF 4 


\section{2-(1R,2S,3R,5R)-5-hydroxy-3-methyl-2-} (nitromethyl)cyclopentyl)acetic acid 6

Method B: Two compounds in an average ratio of (9.6:0.4) were isolated from the flash chromatography; 4 as a pale green oil ( $1.9 \mathrm{~g}$, 94\%). A further elution afforded 6 as a white powder $(81 \mathrm{mg}, 4 \%)$ m.p. $\left(124-126^{\circ} \mathrm{C}\right) ; v_{\max }\left(\mathrm{KBR} / \mathrm{cm}^{-1}\right) 3461,2967,2936,1733,1553$, 1378; $\delta_{\mathrm{H}}\left(400 \mathrm{MHz}, \mathrm{CDCl}_{3}\right) 4.56(1 \mathrm{H}, \mathrm{dd}, \mathrm{J} 8.8 \mathrm{~Hz}, \mathrm{~J} 3.6 \mathrm{~Hz}$, $\left.\mathrm{CH}_{2} \mathrm{NO}_{2}\right), 4.29\left(1 \mathrm{H}, \mathrm{dd}, \mathrm{J} 8.3 \mathrm{~Hz}, \mathrm{~J} 3.6 \mathrm{~Hz}, \mathrm{CH}_{2} \mathrm{NO}_{2}\right), 3.41(1 \mathrm{H}, \mathrm{m}$, $\mathrm{CHOH}), 2.42-2.36\left(2 \mathrm{H}, \mathrm{m}, \mathrm{CH}_{2} \mathrm{C}=\mathrm{O}\right), 2.01(1 \mathrm{H}, \mathrm{m}, \mathrm{CHCHOH}), 1.86-$ $1.83\left(1 \mathrm{H}, \mathrm{m}, \mathrm{CH}_{2} \mathrm{CHOH}\right), 1.78-1.74\left(1 \mathrm{H}, \mathrm{m}, \mathrm{CHCH}_{2} \mathrm{NO}_{2}\right), 1.68-1.64$ $\left(1 \mathrm{H}, \mathrm{m}, \mathrm{CHCH}_{3}\right), 1.58-1.56\left(1 \mathrm{H}, \mathrm{m}, \mathrm{CH}_{2} \mathrm{CHOH}\right), 1.08(3 \mathrm{H}, \mathrm{d}, \mathrm{J} 6.4$ $\left.\mathrm{Hz}, \mathrm{CH}_{3}\right) ; \delta_{\mathrm{c}}\left(100 \mathrm{MHz}, \mathrm{CDCl}_{3}\right)$ 173.3, 78.1, 72.2, 49.5, 40.1, 32.6, 31.8, 30.6, 17.1; m/z (C.I) $218\left(\mathrm{MH}^{+}, 13 \%\right), 200$ (77\%), 137 (25\%), $107(100 \%) \mathrm{C}_{9} \mathrm{H}_{16} \mathrm{NO}_{5}$, requires 208.1029, found 208.1029. (3a, $R, 4 S, 5 R, 6 a S)-4-($ aminomethyl)-5-methylhexahydrocyclopenta[b]furan-2-one 5

Method C: Three compounds were isolated from the column chromatography; 4 as a pale green oil $(449 \mathrm{mg}, 25 \%), 6(1.1 \mathrm{~g}, 55 \%)$ and finally 5 (196 mg, 12\%) having; U $\max$ (thin film/ $\left./ \mathrm{cm}^{-1}\right), 3402,2957$, 1718, 1549; $\delta_{\mathrm{H}}\left(400 \mathrm{MHz}, \mathrm{CDCl}_{3}\right) 4.49\left(2 \mathrm{H}, \mathrm{d}, \mathrm{J} 6.6 \mathrm{~Hz}, \mathrm{CH}_{2} \mathrm{NH}_{2}\right)$, $4.04(1 \mathrm{H}$, ddd, J $5.0 \mathrm{~Hz}, \mathrm{~J} 2.9 \mathrm{~Hz}$, J $2.8 \mathrm{~Hz}, \mathrm{CHOH}), 2.52(1 \mathrm{H}$, dd, J $11.8 \mathrm{~Hz}$, J $\left.4.9, \mathrm{CH}_{2} \mathrm{C}=\mathrm{O}\right), 2.38(1 \mathrm{H}, \mathrm{dd}, \mathrm{J} 9.7 \mathrm{~Hz}, \mathrm{~J} 7.3 \mathrm{~Hz}, \mathrm{~J} 2.3 \mathrm{~Hz}$, $\left.\mathrm{CH}_{2} \mathrm{C}=\mathrm{O}\right), 2.11-2.03\left(2 \mathrm{H}, \mathrm{m}, \mathrm{CHCH}_{2} \mathrm{C}=\mathrm{O}, \mathrm{CHCH}_{3}\right), 1.93-1.83(2 \mathrm{H}$, $\left.\mathrm{m}, \mathrm{CHCH}_{2} \mathrm{NH}_{2}, \mathrm{CH}_{2} \mathrm{CHO}\right), 1.59-1.54\left(1 \mathrm{H}, \mathrm{m}, \mathrm{CH}_{2} \mathrm{CHO}\right), 1.06(3 \mathrm{H}, \mathrm{d}$, J $\left.6.0 \mathrm{~Hz}, \mathrm{CH}_{3} \mathrm{CH}\right) ; \delta_{\mathrm{c}}\left(100 \mathrm{MHz}, \mathrm{CDCl}_{3}\right) 177.0,78.7,77.4,49.7$ 48.8, 41.1, 37.5, 35.6, 19.3; m/z (C.I) $\left.153\left(\mathrm{M}^{+}-\mathrm{NH}_{2}\right), 96 \%\right), 139$ (20\%), $132(28 \%), 109(21 \%), 107(51 \%) \mathrm{C}_{9} \mathrm{H}_{15} \mathrm{NO}_{2}$, requires 153.0916, found, 153.0912 .

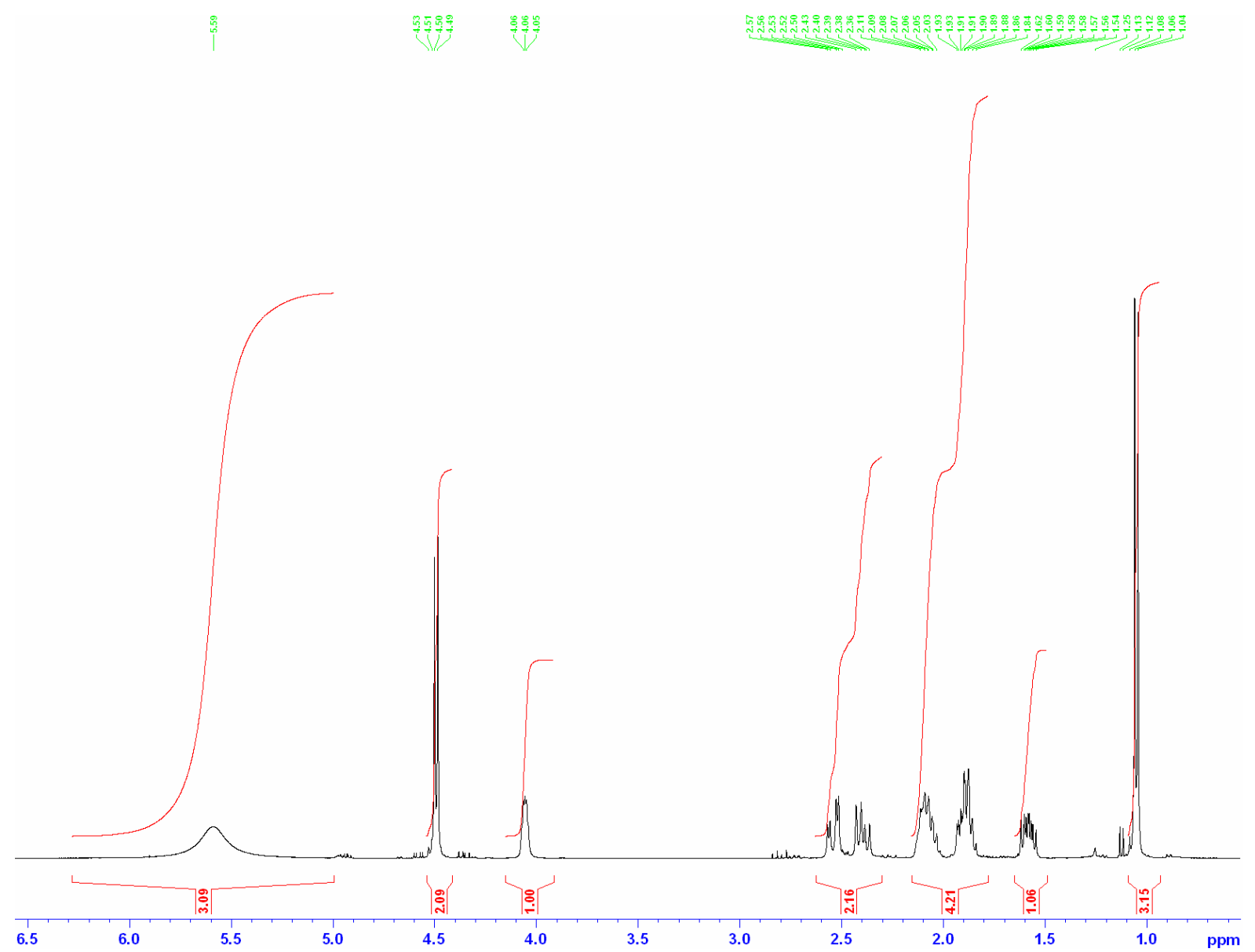

FIG. 3. H NMR OF 5

(3aS,4S,5R,6aS,Z)-3-(hydroxmethylene)-5-methyl-4-(nitromethyl)hexahydrocyclopenta[b]furan-2-one 10

Compound 10 was isolated as a colourless oil ( $127 \mathrm{mg}, 69 \%)$; $v_{\max }$ (thin film) 3412, 2977, 1742, 1642, 1551, 1318, 1139; $\delta_{\mathrm{H}}(250 \mathrm{MHz}$, $\left.\mathrm{CDCl}_{3}\right) 7.03(1 \mathrm{H}, \mathrm{s}, \mathrm{CH}=\mathrm{CC}=0), 4.91(1 \mathrm{H}, \mathrm{ddd}, \mathrm{J} 7.5 \mathrm{~Hz}, \mathrm{~J} 5.0 \mathrm{~Hz}$ $\mathrm{CHO}), 4.49\left(1 \mathrm{H}, \mathrm{dd}, \mathrm{J} 7.5 \mathrm{~Hz}, \mathrm{~J} 5.0 \mathrm{~Hz}, \mathrm{CH}_{2} \mathrm{NO}_{2}\right), 4.33(1 \mathrm{H}, \mathrm{dd}$, $\mathrm{J} 10 \mathrm{~Hz}, \quad \mathrm{~J} 7.5 \mathrm{~Hz}, \mathrm{CH}_{2} \mathrm{NO}_{2}$ ), $\quad 3.17(1 \mathrm{H}, \mathrm{t}, \mathrm{J} 7.5 \mathrm{~Hz}, \mathrm{CHCHO})$,
2.46-2.38 (2H, m, $\left.\mathrm{CHCH}_{3}, \mathrm{CH}_{2} \mathrm{CHO}\right)$, 2.11-2.03 (2H, m, $\mathrm{CHCH}_{2} \mathrm{NO}_{2}$, $\left.\mathrm{CH}_{2} \mathrm{CHO}\right), 1.07\left(1 \mathrm{H}, \mathrm{d}, \mathrm{J} 7.5 \mathrm{~Hz}, \mathrm{CH}_{3}\right) ; \delta_{\mathrm{c}}\left(62.5 \mathrm{MHz}, \mathrm{CDCl}_{3}\right) 174.9$, 158.2, 103.9, 83.3, 74.3, 52.6, 44.6, 41.1, 37.0, 17.6; m/z (C.I) 228 $\left(\mathrm{MH}^{+}, 52 \%\right), 163(100 \%), 153(96 \%), 119$ ( 92\%), 107 (37\%), 93, $(76 \%) \mathrm{C}_{10} \mathrm{H}_{15} \mathrm{NO}_{5}$, requires 228.0873 , found 228.0862 


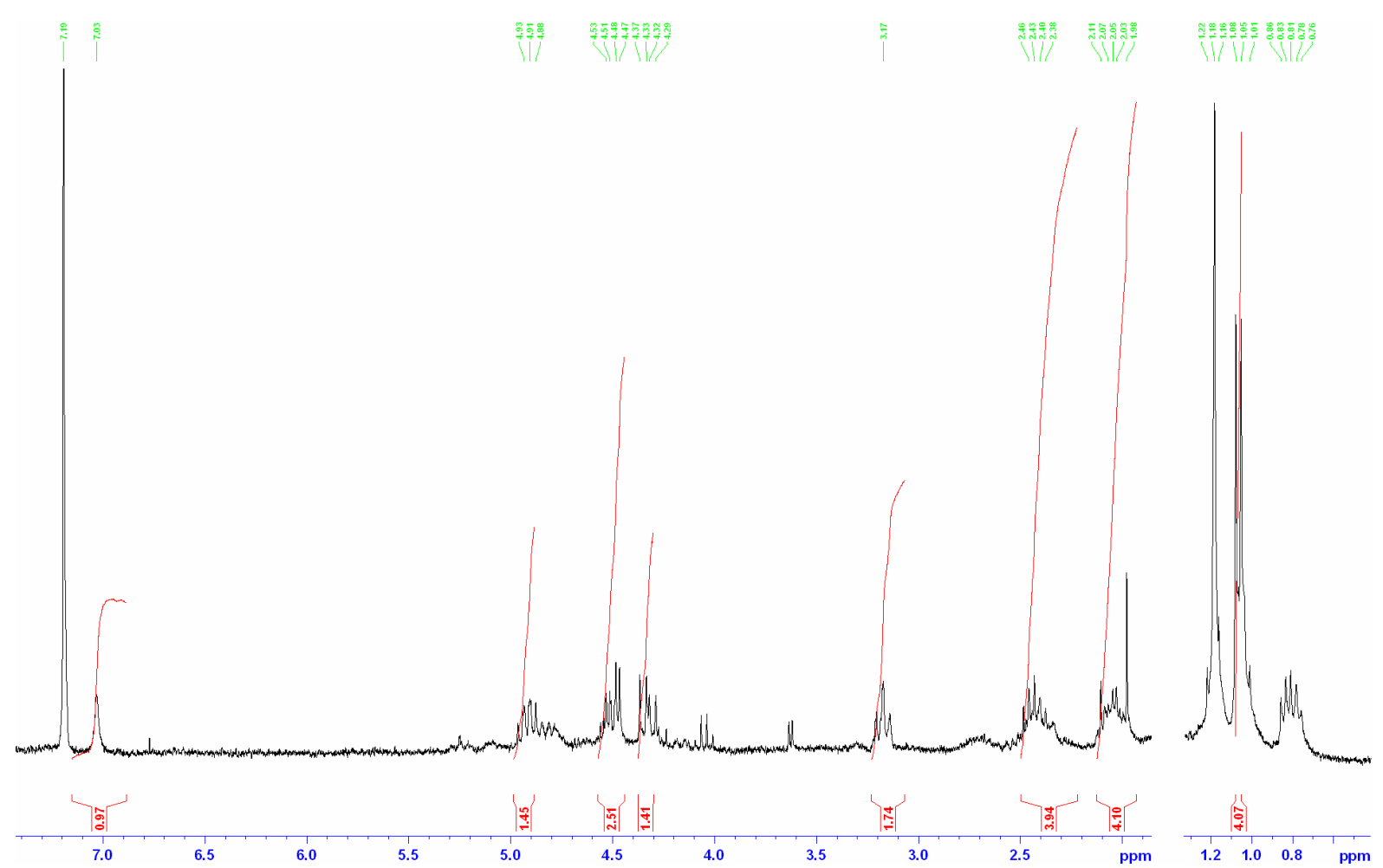

FIG. 4. H NMR OF 10

\section{Iridolactone 11}

The title compound was isolated as a colourless oil (119 mg, 57\%); $U_{\max }$ (thin film/ $\mathrm{cm}^{-1}$ ), 2956, 2933, 2855, 1756, 1663, 1239, 1216, 1171,$1013 ; \delta_{\mathrm{H}}\left(400 \mathrm{MHz}, \mathrm{CDCl}_{3}\right) 7.33(1 \mathrm{H}, \mathrm{d}, \mathrm{J} 2.7 \mathrm{~Hz}, \mathrm{OCH}=\mathrm{C})$, $6.34(1 \mathrm{H}, \mathrm{s}, \mathrm{CHCOOAc}), 5.04(1 \mathrm{H}, \mathrm{t}, \mathrm{J} 4.6 \mathrm{~Hz}, \mathrm{CHO}), 3.43-3.40(1 \mathrm{H}$, $\mathrm{m}, \mathrm{C}=\mathrm{CCH}), 2.20-2.11\left(4 \mathrm{H}, \mathrm{m}, \mathrm{OCOCH}_{3}, \mathrm{CHCHOAc}\right), 1.97-1.94$ $\left(1 \mathrm{H}, \mathrm{m}, \mathrm{CH}_{2} \mathrm{CHCH}_{3}\right), 1.66-1.62\left(1 \mathrm{H}, \mathrm{m}, \mathrm{CH}_{2} \mathrm{CHCH}_{3}\right), 1.26-1.24(1 \mathrm{H}$, m, $\left.\mathrm{CH}_{2} \mathrm{CHCH}_{3}\right), 1.06\left(3 \mathrm{H}, \mathrm{d}, \mathrm{J} 6.3 \mathrm{~Hz}, \mathrm{CHCH}_{3}\right) ; \delta_{\mathrm{c}}\left(100 \mathrm{MHz}, \mathrm{CDCl}_{3}\right)$ 171.4, 168.3, 147.3, 102.9, 87.8, 80.4, 45.1, 42.0, 37.9, 31.2, 20.1, 17.0; $\mathrm{m} / \mathrm{z}$ (C.I) $195\left(\mathrm{MH}^{+}, 100 \%\right), \mathrm{C}_{12} \mathrm{H}_{14} \mathrm{O}_{5}$, requires 239.0920 , found, 239.0917

\section{DISCUSSION}

Reduction of the ketone in 3 with several different reagents was studied using methodology reported by Chaudhuri et al., (1994). It was envisaged that complimentary conditions leading to synselectivity could be achieved as a route to the substituted AB-ring 4 . With each reagent it was decided to study the effect of temperature and metal counterion on the reduction stereoselectivity. In this report the results of the reduction with sodium borohydride stand in contrast to the work by Bornmann et al., (1979) who reported that reduction of keto-esters with sodium borohydride was weakly selective for the syn-alcohol $\left(59: 41 ; 0^{\circ} \mathrm{C}, 76 \%\right)$. However, the result with sodium borohydride (Scheme 2) showed consistency with earlier that established greater selectivity for the anti-alcohol, (syn:anti ratio 35:36; $0{ }^{\circ} \mathrm{C}$ ) (Bornmann et al., 1979; Lalande \& Larcheveque,1985; Chaudhuri et al., 1994).

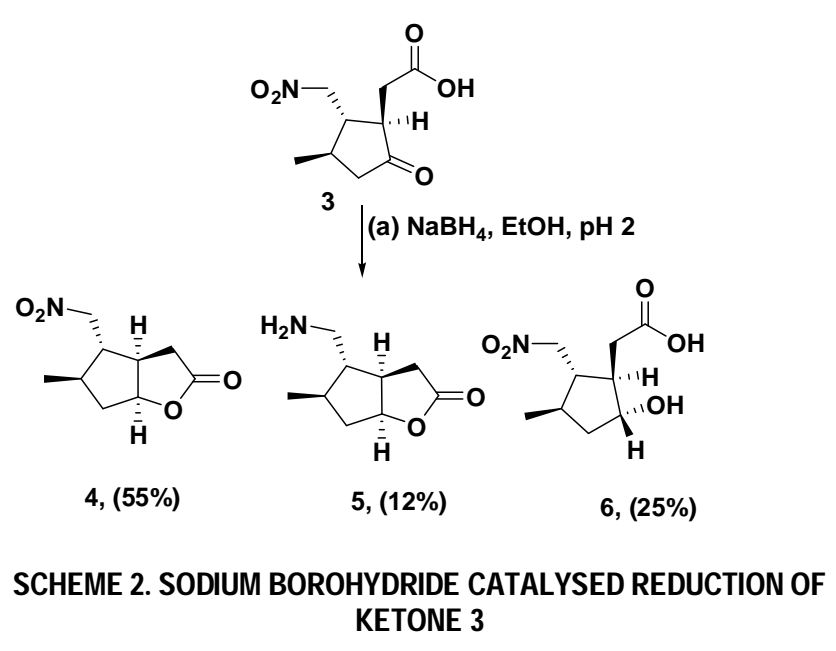

Reduction of the ketone 3 with sodium borohydride in methanol at $0{ }^{\circ} \mathrm{C}$ furnished syn- 4 and anti- 6 as colourless oils with a syn:anti ratio (20:65; $0{ }^{\circ} \mathrm{C}$ ). The result was also found to be invariant with respect to temperature change. However, when the reaction was repeated at room temperature for 1 hour, TLC analysis showed the appearance of a new product. The solvent was removed under reduced pressure and the residue was subjected to gradient column chromatography to permit the isolation of 5 in addition to 4 and 6 with a ratio of (13:27:60; rt) 
respectively. In each case, their masses, IR and ${ }^{1} \mathrm{H}$ NMR spectra fully supported the proposed structures 4,5 and 6 . (Scheme 2). Stereochemical assignment of (3aR,4S,5R,6aS)-5-methyl-4(nitromethyl)-hexahydrocyclopenta[b]furan-2-one 4 was done using nOe (Fig 2). An enhancement of the C-6 methine was seen when $\mathrm{H}$ 4 was irradiated signifying the two protons on C-4 and C- 6 are on the same face of the molecule. In the same vein, an enhancement of the $\mathrm{H}-7$ methine proton was also observed when $\mathrm{H}-4$ methine proton was irradiated

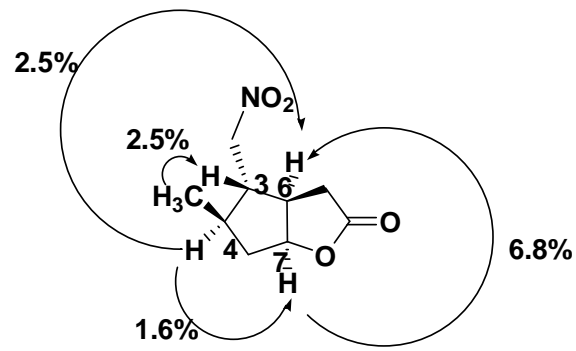

\section{FIG 5. RESULT FOR THE NOE EXPERIMENT OF PRECUSOR 4}

In an attempt to achieve syn-alcohol selectivity, sterically bulky reagents were considered as suitable reagents. It was decided to examine the reduction using commercially available reagents $(L$ and $\mathrm{K}$-Selectrides). It was anticipated that reduction with these reagents, which are very bulky and have low coordinating ability, could follow the model of Felkin and Anh (Anh et al., 1973). Since the reduction proceeds by initial complexing of the metal boron with the carbonyl oxygen, the favoured transition state conformer becomes either 8 or 9. Attack of the nucleophile is easier via the dotted arrow shown in 8 (Scheme 3)<smiles>[M]C(S)(I)C(C)=O</smiles>

7

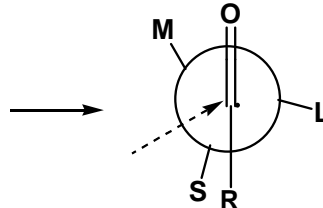<smiles>[R]C1CC([3H])CC2(C)C(=O)CC1(C)C([M])C2S</smiles>

In accord with plan, the Selectride reagents produced syn-alcohol selectivity under all conditions studied. The steroselectivity with the two reagents increases with decreasing temperature to produce the diastereoisomers 4 and 6 . It was also noted that this trend expressed the increasing importance of the Felkin and Anh model conformer 8. The highest selectivity was achieved with K-Selectride ${ }^{\circledR}$ at $-78{ }^{\circ} \mathrm{C}\left(100 \%\right.$ syn-selectivity) and L-Selectride ${ }^{\circledR}$ (96:4 synselectivity) (Table 1).

\section{TABLE 1. STEREOSELECTIVITY OF REDUCTION} OF KETONE 3

\begin{tabular}{lcc}
\hline Reagents & Temp $\left({ }^{\circ} \mathrm{C}\right)$ & syn- 4: anti- 6:5 \\
\hline \multirow{2}{*}{$\mathrm{NaBH}_{4}$} & $\mathrm{RT}$ & $27: 60: 13$ \\
& $0^{\circ} \mathrm{C}$ & $20: 65$ \\
& $-78{ }^{\circ} \mathrm{C}$ & $18: 79$ \\
\hline \multirow{2}{*}{ K- } & $\mathrm{RT}$ & $76: 24$ \\
Selectride $^{\circledR}$ & $0^{\circ} \mathrm{C}$ & $82: 18$ \\
& $-78^{\circ} \mathrm{C}$ & $100: 0$ \\
\hline \multirow{2}{*}{ L- $_{\text {Selectride }}^{\circledR}$} & $\mathrm{RT}$ & $68: 32$ \\
& $0^{\circ} \mathrm{C}$ & $80: 20$ \\
\hline
\end{tabular}

\section{Strategies for Assembling Iridolactone Core}

In an initial investigation, formylation of the nitro-ester was achieved by treatment of 4 with 4 equivalents of sodium hydride to generate the carbanion. Subsequent addition of ethyl formate in ether furnished the enol ester 10 . The ${ }^{1} \mathrm{H}$ NMR spectrum of this product showed a distinct one proton resonance due to enol centred at $\delta 7.03 \mathrm{ppm}$. The possibility that 10 could be employed in a Nef reaction was considered on the basis of a report by Kosta \& Poupart (1985) that nitro groups can be converted to aldehydes with aq. $\mathrm{KMnO}_{4}$. It was decided to modify this procedure to test the possibility of immediate protection of the cyclised alcohol formed as its acetate. This was fortunate, as it had been hoped; nito-ester 10 was added to a stirred solution of sodium hydroxide followed by dropwise addition to an ice cold water mixture of sulphuric acid and stirring continued for 1 hour. Acetic anhydride was added to the mixture and stirring continued for further 12 hours to permit the isolation of 11 in good yield (Scheme 4).

SCHEME 3. MECHANISM FOR STEREOCONROL REDUCTION WITH SELECTRIDES

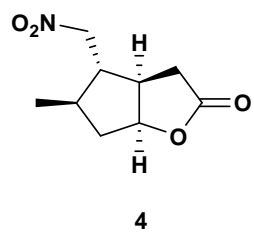

(a) $\mathrm{NaH}, \mathrm{Et}_{2} \mathrm{O}$, ethyl formate<smiles>CC1C[C@H]2OC(=O)/C(=C/O)[C@H]2[C@H]1C[N+](=O)[O-]</smiles>

$10,(69 \%)$ (b) $\mathrm{NaOH}, \mathrm{H}_{2} \mathrm{SO}_{4}$, acetic anhydride<smiles>CC(=O)O[C@@H]1C=C2C(=O)O[C@@H]3CC(C)[C@H]1[C@H]23</smiles>

$11,(57 \%)$

SCHEME 4. CONSTRUCTION OF IRIDOLACTONE CORE

\section{CONCLUSION}

A three-step enantio-enriched synthesis of the model tricyclic core was developed. There is a noteworthy discovery in the reduction methods of precursor 3 for the preparation of the tricyclic ring system. Notwithstanding the limitations imposed by other reducing agents, the reduction works with K-Selectride ${ }^{\circledR}$.

Thus, the enantioenriched precursor 3 was converted to lactone 4 by treatment with K-Selectride ${ }^{\circledR}$. The overall yield of this K-Selectride ${ }^{\circledR}$ led reduction was $85 \%$ (100\% syn selectivity). Formylation was successfully carried out by treating the lactone 4 with ethyl formate given enol ester 10 which readily undergo a Net reaction to the model tricyclic core 11.

\section{REFERENCES}

Amarego, W. L. F. \& Perrin, D. D. (1998). Purification of Laboratory Chemicals, Pergamon Press Oxford 
Anh, N. T., Eisenstein, O. \& Lefour, J. M. (1973). Orbital factors and asymmetric induction. Journal of the American Chemical Society. 95:6146

Bornmann W. G., Lipkowitz, K. B. \& Mundy, P. (1979). Formation and synthetic utility of dihydro- and dihydrothiapyrans. Journal of Organic Chemistry. 44:486

Castro, O. \& Umana E. (1990). Chemical constituents of Verbena littoralis. Int. J. Crude Drug Research. 28:175.

Chaudhuri, N. C., Reddy, M. V. \& Vankar, Y. D. (1994). Chiral acetals in Organic synthesis. Regioselective synthesis of 2- and 3hydroxy acetals from 2,3-olefinic acetals: Reinvestigation and further applications. Tetrahedron. 50:11057

Ford, R., Ménard, M. \& Robertson, J. (2004). An Approach to the Tricyclic Lactone Core of Brasoside and Related Natural Products. Synlett. 2788.
Ishibashi, M., Kimihoro, M., Li, Y. S. \& Ohizumi, Y. (2001). Littoralisone, a Novel Neuritogenic Iridolactone Having an Unprecedented Heptacyclic Skeleton Including Four- and NineMembered Rings Consisting of Glucose from Verbena littoralis. Journal of Organic Chemistry. 66:2165.

Kosta, S., \& Poupart, M. (1985). Reagents for organic synthesis. 5. Synthesis of aldehydes and ketones from nitro paraffins. Journal of Organic Chemistry. 50:4971

Lalande, J. \& Larcheveque, M. (1985). Highly stereoselective preparation of enantiomerically pure 1,2-diols: synthesis of $(+)$ exobrevicomin. Journal Chemical Society, Chemical Communication. 83

Macmillan, D. W. C. \& Mangion, I. K. (2005). Total Synthesis of Brasoside and Littoralisone. Journal of the American Chemical Society.127:3697. 